\title{
DINAMIKA PENENTUAN BULAN RAMADHAN DAN SYAWAL PADA MASYARAKAT EKSKLUSIF DI KABUPATEN GOWA
}

\author{
Rahmatiah HL \\ rahmatiah69@gmail.com
}

\begin{abstract}
Abstrak
Tulisan ini mengkaji tentang dinamika penentuan awal bulan ramadhan dan syawal pada masyarakat eksklusif dengan mendeskripsikan metode Hisab dan rukyat yang digunakan jamaah an-Nadzir dan Naksabandiyah di kabupaten Gowa. Tujuannya untuk mengungkap pengaruh imam pada pengambilan keputusan dalam menggambarkan besarnya pengaruh tanda-tanda alam sebagai objek terhadap pengambilan keputusan penetapan dalam menetapkan awal ramadhan dan Syawal pada jamaah an-Nadzir dan Naksabandiyah di kabupaten Gowa. Penentuan awal bulan kamariyah terkhusus pada pelakasanaan ibadah (puasa dan idul fitri dan idul adha) dengan menggunakan hisab memiliki kedudukan yang benar secara teoritik, sedangkan dengan menggunakan hisab akan menguatkan hisab secara empirik. Olehnya diperlukan integrasi kedua metode tersebut agar memberikan keyakinan yang haq/ilmiah kepada ummat.
\end{abstract}

\section{Pendahuluan}

Masyarakat kabupaten Gowa adalah masyarakat religious yang taat menjalankan perintah dan ajaran agamanya sesuai keyakinannya, disamping sebagai masyarakat sebagai makhluk yang kreatif dan produktif. Ke- religious-an masyarakat kabupaten Gowa tercermin dari cara dan kegiatan ibadah yang dilakukan secara turun temurun dilakukan hingga saat ini, begitu pula pola kegiatan adat istiadatnya masih mencerminkan sikap dan pemahaman keagamaan yang mendalam. Adanya kegiatan maudu lompoa di Cikoang, Takalar, tata cara menghadadapi Ramadhan dan Syawal pada masyarakat Naksyabandiyah dan Jamaah Az-Nadzir adalah salah satu bukti kereligiousan tersebut.

Agama dan keyakinan pemeluknya membuat orang melakukan aktivitas agamanya harus bersesuaian dengan apa yang diajarkan, demikian pula dengan masyarakat kabupaten Gowa yang cenderung menjalankan segala aktivitasnya berdasarkan perintah ajaran agama dan keyakinannya, termasuk masyarakat naksabandiyah dan masyarakat jamaah an-Nadzir. Salah satu diantara kegiatan aktivitas agama kedua golongan ini adalah cara dan metode penetapan awal bulan 
kamariyah yang berbeda dengan kementerian agama RI, bahkan ada yang menentukan Ramadhan dan Syawalnya melalui fenomena pasang surut nya air laut, atau air danau.

Penentuan awal bulan Qamariyah penting artinya bagi umat Islam sebab selain untuk menentukan hari-hari besarnya juga untuk menentukan awal dan akhir bulan Ramadhan, Syawal, dan zulhijjah. Masalah ini menyangkut wajib ain bagi setiap umat Islam yang menjalankan ibadah puasa. Permasalahan penentuan awal bulan Ramadhan dan Syawal merupakan permasalahan klasik tetapi aktual dan hangat dibicarakan di lingkungan masyarakat Islam dan menjadi perbincangan setiap tahun apalagi yang menyangkut penentuan awal bulan Ramadhan dan Syawal di kalangan masyarakat kabupaten Gowa

Penentuan awal bulan kamariayah sangat penting artinya bagi segenap kaum muslimin, sebab banyak macam ibadah dalam Islam yang pelaksanaannya dikaitkan dengan perhitungan bulan qamariyah. Di antara ibadah-ibadah itu adalah shalat dua hari raya yaitu: shalat iedul fitri dan shalat iedul adha (kurban), shalat gerhana bulan, shalat gerhana matahari, perhitungan waktu haji dan sebagainya.

Untuk menentukan awal bulan qamariyah, syariat Islam telah memberikan pedoman dalam penetapannya seperti dalam Q.S. al-Isra' (17) ayat (12); Q.S. ArRahman (55) ayat (5); sebagai berikut:

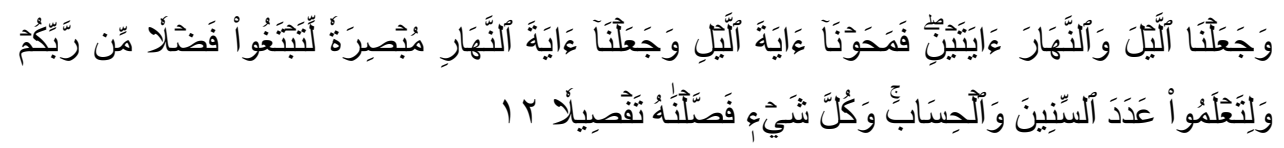

Terjemahnya:

Dan Kami jadikan malam dan siang sebagai dua tanda, lalu Kami hapuskan tanda malam dan Kami jadikan tanda siang itu terang, agar kamu mencari kurnia dari Tuhanmu, dan supaya kamu mengetahui bilangan tahuntahun dan perhitungan. Dan segala sesuatu telah Kami terangkan dengan jelas. ${ }^{1}$

${ }^{1}$ Kementerian Agama RI, al-Qur`an dan Terjemahnya, h. 283. 
dan Q.S. al-Baqarah (2) ayat (185), juga memberi petunjuk tentang penetapan awal Ramadhan, seluruh ayat tersebut menunjukkan isyarat penentuan awa bulan Kamariyah. Seiring dengan petunjuk al-quran, Rasulullah saw memberi pedoman penetapan awal bulan lewat hadis yang diriwayatkan oleh Imam Bukhari:

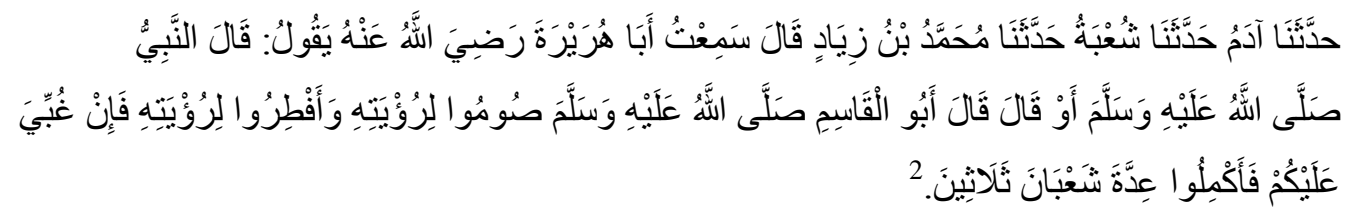

Artinya:

Berpuasalah karena kamu melihat hilal dan berbukalah karena kamu melihat hilal, apabila hilal itu tertutup kabut olehmu maka sempurnakanlah bilangan sya ‘ban 30 hari. $^{3}$

Bertolak dari dalil tersebut diatas, dapat disimpulkan bahwa teknik atau metode penentuan awal bulan Ramadha dan Syawal ada dua cara yaitu dengan melihat bulan (rukyat) dan dengan mencukupkan bilangan hari (hisab). Jadi penentuan awal Ramadhan boleh jadi dengan cara hisab, dan boleh jadi dengan cara rukyat, atau bahkan keduanya (hisab dan rukyat). Di sisi lain ada segolongan masyarakat yang menamakan diri sebagai jamaah an-Nadzir dan Naksabandiyah yang selalu melakukan puasa ramadhan dan lebaran pada bulan Syawal dilakukan lebih awal dari ummat muslim lainnya di Indonesia.

Komunitas an-Nadzir ini mulai mengorganisir diri sebagai organisasi keagamaan dan berawal dari tanah Luwu. Jamaah ini adalah komunitas Islam yang unik dan asing bila dibanding dengan komunitas Islam lainnya. Mereka hidup sangat sederhana dan mandiri. Keberadaannya selalu membawa kedamaian dan suasana aman terhadap lingkungan luar sekitarnya. Sifat gerakan

${ }^{2} I m a \bar{m}$ Abī 'Abdillāh Muḥammad bin Ismā’̄̄l al-Bukhārī, Șaḥịh Bukhārī, (Lebanon: Dār Kutub al-'Ilmiyyah, 2009), h. 470.

${ }^{3}$ Rahmatiah, Analisis Perbedaan Persepsi Ahli Hisab dan Ahli Rukyat dalam Penentuan Awal Bulan Qamariyah (Cet. I;Makassar: Alauddin Press, 2014), 40-41. 
keagamaannya cenderung ekslusif, namun tetap terbuka dan akomodatif dalam hal ekonomi dan sosial.

Masyarakat Naksabandiyah di kabupaten Gowa pun tidak jauh berbeda dengan jamah an-Nadzir, pun mereka punya cara dan metode lain dan berbeda dengan kementerian agama RI, dan keunikan inilah yang menyebabkab penulis tertarik mengkaji lebih focus dan akan menjadikan sebagai objek kajian dalam penelitian kali ini. Jamaah an-Nadzir dan masyarakat naksabandiyah dalam hal menetapkan awal bulan Ramadhan dan Syawal mereka melihat tanda-tanda alam, dan menurut petunjuk dari pemimpin tau khalifah mereka misalnya pasang surut air laut dan juga berakhirnya bulan Sya'ban pada tanggal 27 Juni 2014 tepat matahari di atas ubun-ubun. ${ }^{4}$

Keunikan cara penentuan awal bulan Ramadhan dan Syawal pada jamaah an-Nadzir dan masyarakat nakzabandiyah di Kabupaten Gowa ini menjadi menarik dan sangat penting untuk dipublikasikan mengingat kehidupan komunitas ini berbeda dari segi srtuktur keagamaan dan paham keislaman. Kegiatan yang berkaitan dengan ibadah, sosial dan pendidikan bahkan lingkungan yang sangat unik mendorongpenulisuntuk mengangkat dan mengkaji keunikan pada kelompok jamaah an-Nadzir dan masyarakat Naksabandiyah.

Berangkat dari uraian di atas, makapenulismerumuskan masalah pokok dalam penelitian ini sebagai berikut: "Bagaimanakah metode penentuan awal ramadhan dan syawal pada jamaah an-Nadzir dan Naksabandiyah di Kabupaten Gowa?" dengan Sub Masalah: Bagaimanakah metode Hisab dan rukyat yang digunakan jamaah an-Nadzir dan Naksabandiyah di kabupaten Gowa? Bagaimanakah pengaruh imam pada pengambilan keputusan dalam menetapkan awal ramadhan dan Syawal pada jamaah an-Nadzir dan Naksabandiyah di kabupaten Gowa? Berapa besar pengaruh fenomena alam terhadap pengambilan keputusan penetapan awal Ramadhan dan Syawal pada Jamaah an-Nadzir dan jamaah Naksabandiyah di Kabupaten Gowa.

\footnotetext{
${ }^{4}$ http://daerah.sindonews.com, selasa, 4 April 2017
} 


\section{A. Tinjauan Umum tentang Hilal}

1. Hilal dalam Al-Qur'an

Allah swt menyebutkan dalam QS. al-Baqarah/2: 189 terkait dengan pertanyaan para sahabat kepada Nabi SAW tentang ahillah (jamak dari hilal):

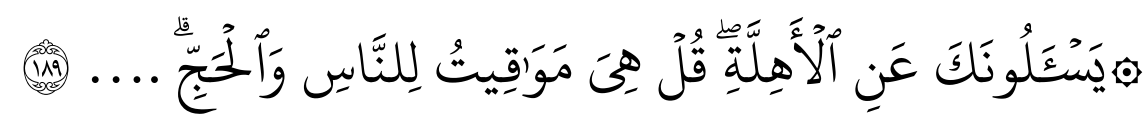

Terjemahnya:

Mereka bertanya kepadamu tentang bulan sabit. Katakanlah: "Bulan sabit itu adalah tanda-tanda waktu bagi manusia dan (bagi ibadat) haji..."

Allah swt menurunkan ayat ini sebagai penjelasan terhadap pertanyaan orang arab tentang bulan sabit, yang pada dasarnya berkaitan pula dengan pelaksanaan agama yang berhubungan dengan pengunaan waktu. ${ }^{6}$ Ayat ini menunjukkan bahwa ahillah atau hilal itu sebagai kalender bagi kehidupan manusia dan ibadah, termasuk ibadah haji. Pertanyaan itu muncul karena sebelumnya para sahabat telah melihat penampakan hilal atau dengan kata lain hilal telah tampak terlihat oleh para sahabat.

Para mufassir telah mendefinisikan, bahwa hilal itu pasti tampak terlihat. Al-Maraghi dalam tafsirnya mengemukakan sebuah riwayat dari Abu Na'im dan Ibnu 'Asakir dari Abi Sholih dan Ibnu Abbas menceritakan:

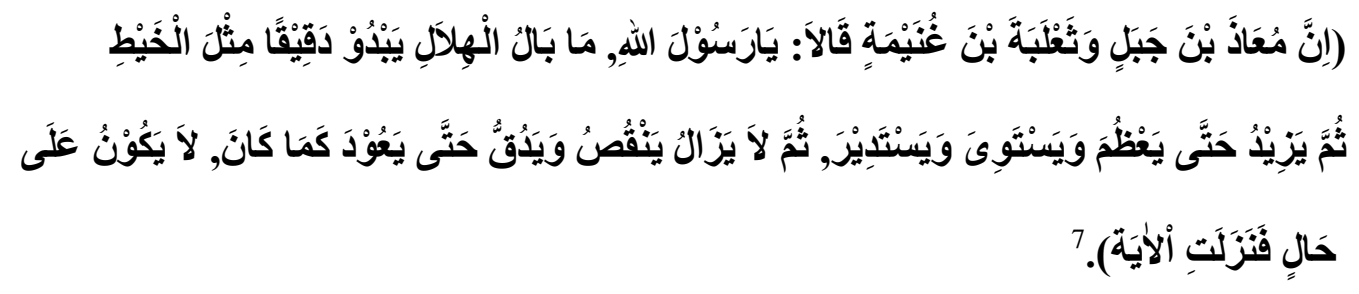

Artinya:

Sesungguhnya Mu'adz bin Jabal dan Tsa'labah bin Ghunaimah bertanya: Ya Rasulallah, mengapa keadaan hilal itu tampak lembut cahayanya laksana benang, selanjutnya bertambah sehingga membesar, merata dan bundar, dan

\footnotetext{
${ }^{5}$ Kementerian Agama RI, al-Qur`an dan Terjemahnya, h. 29.

${ }^{6}$ Abi Tahir Ya`kub Fayr al-Zabadi, Tanwir al-Miaqbas min Tafsir Ibnu Abbas (Bairut: Dar al-Fikr, t.th), 26.

${ }^{7}$ Syaikh Ahmad Musthofa Al-Maroghi, Tafsir al-Maraghi jilid I (Cet.I; Kairo: Musthofa Al-Babi Al-Halabi, 1946), h. 84.
} 
kemudian berangsur-angsur menyusut dan melembut sehingga kembali seperti keadaan semula, tidak dalam satu bentuk?” Maka turunlah ayat ini.

Sementara itu, Ash-Shabuni dalam tafsirnya Shafwatut Tafasir juz I mengemukakan tafsir ayat tersebut sebagai berikut:

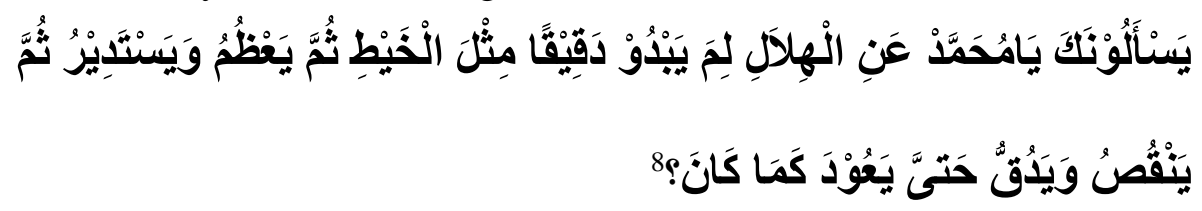

Artinya:

Mereka bertanya kepadamu hai Muhammad tentang hilal mengapa ia tampak lembut semisal benang selanjutnya membesar dan terus membulat kemudian menyusut dan melembut sehingga kembali seperti keadaan semula?.

Sayyid Quthub dalam tafsirnya Fi Zhilalil Qur'an juz I, menafsirkan ayat tersebut sebagai berikut:

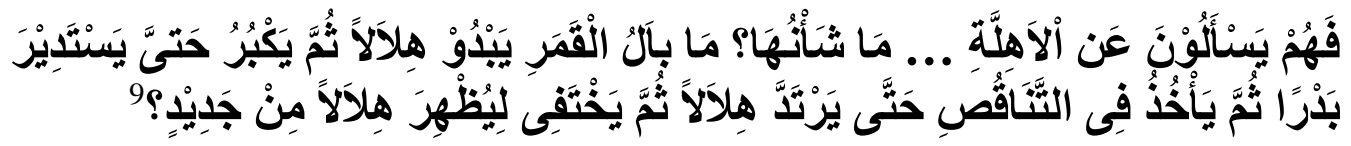

Artinya:

Maka mereka bertanya tentang ahillah (hilal) ... bagaimana keadaan ahillah (hilal)? Mengapa keadaan qamar (bulan) menampakkan hilal lalu membesar sehingga bulat menjadi purnama selanjutnya berangsur menyusut sehingga kembali menjadi hilal lagi dan kemudian menghilang tidak tampak untuk selanjutnya menampakkan hilal dari (bulan) baru?.

Al-Maraghi dalam tafsirnya jilid 4, menafsirkan QS Yunus/10: 5 ayat

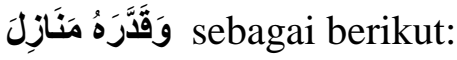

${ }^{8}$ Muhammad Aly Ash-Shabu>ni, Shafwatut Tafa $>$ sir juz I (Bairut: Dar al-Kutub alIslamiyah, t.th), h. 125.

${ }^{9}$ Sayyid Quthub, Fi> Zhila $>$ lil Qur'a $>n$ juz I, (Cet.XXVII; Mesir: Dar al-Syuruk, 1998 M/1419IH), h. 178.

${ }^{10}$ Sayyid Quthub, Fi> Zhilalil Qur'a>n juz I, terjemahan oleh As`ad Yasin, Tafsir Fi Zhilaalil Qur'an (Cet.VI; Jakarta: Gema Insani Press, 2008), h. 256. 


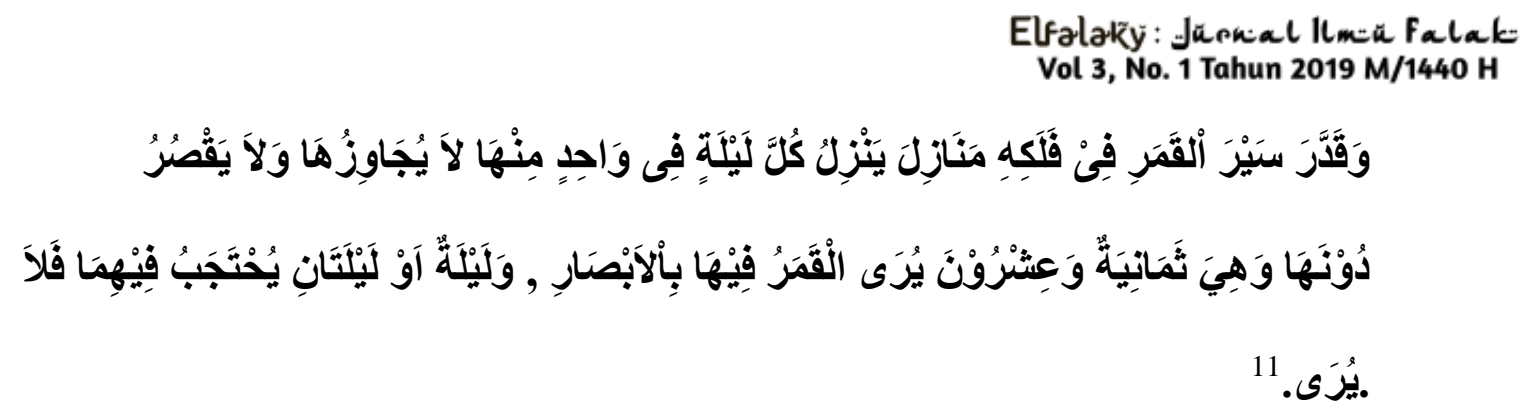

Artinya:

Allah menetapkan perjalanan bulan pada orbitnya beberapa manzilah; setiap malam menempati satu manzilah; tidak akan melampaui dan tidak berkurang dari padanya. Adapun manzilah-manzilah itu ialah 28 manzilah yang di dalamnya bulan terlihat oleh mata, dan 1 malam atau 2 malam bulan tertutup, maka tidak dapat dilihat.

Kata ahillah menurut Wahbah al Zuhayliy dalam al-Tafsir al-Munir merupakan bentuk jama' dari hilal Digunakan bentuk jamak karena Bulan tampak dari Bumi dalam berbagai ukuran (fase). Pada dua atau tiga malam per-tama di setiap awal bulan, Bulan nampak kecil. sesudah itu ukuran penampakan Bulan terus bertambah hingga penuh (purnama, badr, full moon). Lalu kembali mengecil seperti semula. Artinya, penampakan bulan tidak berada dalam satu keadaan seperti Matahari. Disebut hilal karena ia "tampak" sesudah menghilang. ${ }^{12}$ Menurut Imam Syaukani menerangkan tentang hilal yang muncul setiap bulannya (Bulan Sabit) atau muncul setiap harinya (Bulan sempurna). Hilal muncul sebagai penentu perbedaan waktu dan keteta pan alat waktu guna menentukan kapan terjadinya waktu beribadah kepada Allah. Sedangkan hilal itu sendiri menurut Imam Syaukani memiliki makna yaitu sebuah nama bulan yang muncul di setiap awal bulan dan akhir bulan. ${ }^{13}$

Penafsiran ini mengisyaratkan bahwa dari observasi bulan al-Maraghi berkesimpulan, awal bulan ditandai dengan penampakan hilal yang dapat dilihat dengan mata di awal malam (sesaat setelah matahari terbenam). 27 manzilah berikutnya, yakni tanggal 2 sampai dengan 28, bulan dapat dilihat dengan mata.

\footnotetext{
${ }^{11}$ Syaikh Ahmad Musthofa Al-Maroghi, Tafsir al-Maraghi jilid IV, h. 64.

${ }^{12}$ Wahbah Al-Zuhayliy, al-Tafsir al-Manar Juz 2 (Beirut: Dar al-Fikr al-Mua’asir, 1411 H/1991 M), h. 169.

${ }^{13}$ Muhammad bin `Ali> bin Muhammad Al-Syauka>ni>, Fathul al-Qadir al-Jami’ Baina Fanni al-Riawayah Wa al-Dirayah min Ilmi al-tafsir, Juz I (Cet. II; Mesir, Dar al-Qafa' Mansurah, 1997M/1418H), h. 343.
} 
Manzilah ke-29 atau ke-30, bulan tidak dapat dilihat dengan mata. Penafsiran yang sama juga dilakukan al-Maraghi terhadap surat Yasin ayat 39. Jelaslah menurut ayat-ayat al-Qur'an dan tafsirnya tersebut, bahwa hilal atau bulan sabit itu pasti tampak terlihat.

\section{Hilal dalam Hadis}

Dalam hadis yang Mu'adz bin Jabal dan Tsa'labah bin Ghunaimah tersebut di atas:

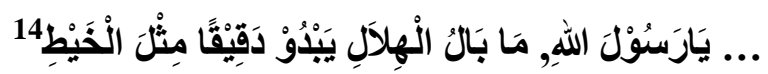

Artinya :

Ya Rasulallah, mengapa keadaan hilal itu tampak lembut cahayanya laksana benang. ${ }^{15}$

Sedangkan kata hilal dalam hadits yang berkaitan dengan penentuan awal bulan kamariyah yang diriwayatkan Imam Bukhary.

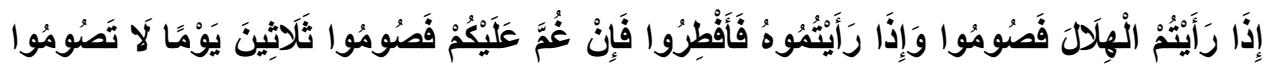

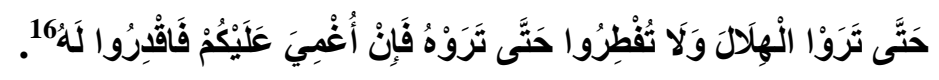

Artinya:

Janganlah kalian berpuasa hingga kalian melihat hilāl dan jangan pula berbukan hingga melihatnya (terbit) kembali. Namun, jika bulan itu tertutup dari pandanganmu, makan hitunglah.

Rasulullah saw, menganjurkan sahabatnya untuk melihat hilal dalam rangka membuktikan terbitnya bulan Ramadhan untuk melaksanakan ibadah puasa dan pelaksanaan hari raya. ${ }^{18}$ Hal ini bermakna secara astronomis bahwa umat dianjurkan untuk berusahan mengetahui posisi hilal pada saat matahari

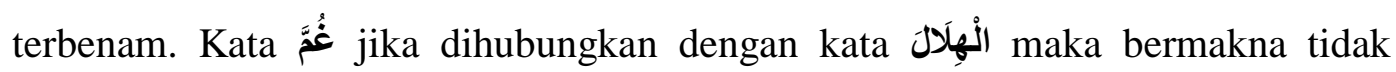
tampak karena tertutup awan. ${ }^{19}$

\footnotetext{
${ }^{14}$ Abi Tahir Ya`kub Fayr al-Zabadi, Tanwir al-Miaqbas min Tafsir Ibnu Abbas, h. 157.

${ }^{15}$ Ambo Asse, Metode Hisab Rukyat dalam Persfektif Hadits Nabi saw (Cet.I; Makassar: Alauddin Press, 2011),h. 242.

${ }^{16}$ Imām Abī 'Abdillāh Muhammad bin Ismā’n̄l al-Bukhārī, Jami` Shahih al-Muhthoshar Jilid II (Maktabah Syamilah, t.th), h. 676.

${ }^{17}$ Ambo Asse, Metode Hisab Rukyat dalam Persfektif Hadits Nabi saw, h. 214.

${ }^{18}$ Ambo Asse, Metode Hisab Rukyat dalam Persfektif Hadits Nabi saw, h. 216.

${ }^{19}$ Ahmad Warson Munawwir, Al-Munawir: Kamus Arab Indonesia, h. 1094..
} 
Selanjutnya dalam hadislain disebutkan, hadis yang diriwayatkan oleh Imam Ahmad dan Abu Daud, riwayat Rib'i bin Hirasy dari salah seorang sahabat Rasulullah SAW bahwa para shahabat berbeda pendapat tentang akhir ramadhan, di tengah-tengah perbedaan itu datanglah dua orang a'robi melaporkan kepada Rasulullah SAW dan bersumpah:

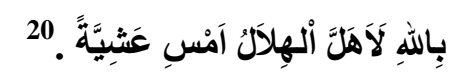

Artinya:

Demi Allah sungguh telah tampak hilal kemarin sore.

Hadis di atas menyatakan bahwa hilal itu pasti tampak terlihat sesuai dengan pengertian bahasanya. Dari tinjauan bahasa, Al-Qur'an/tafsir, As-Sunnah dapat disimpulkan bahwa hilal (bulan sabit) itu pasti tampak cahanya terlihat dari bumi di awal bulan, bukan sekedar pemikiran atau dugaan adanya hilal. ${ }^{21}$ Dari beberapa defenisi tentang hilal menurut para mufasir dan fuqaha tersebut dapat disimpulkan bahwa hilal adalah penampakan bulan muda (bulan sabit) setelah terjadi ijtimak yang terlihat pada awal bulan pada malam kesatu, kedua dan ketiga pertanda masuknya awal bulan dimulai dalam sistem kalender hijriyah.

\section{Metode Penentuan Awal Bulan Kamariyah}

Hisab dan Rukyat sejatinya merupakan dua sistem dalam menentukan awal bulan Islam, kegunaanya untuk menentukan momentum-momentum penting dalam Islam, seperti awal Ramadhan, Syawal Dan Dzulhijjah sebagai awal puasa maupun hari raya, selain itu juga digunakan dalam menentukan waktu ibadah lainya seperti salat dan lain sebagainya. ${ }^{22}$

Secara epistemologi hisab dan rukyat dapat dibenarkan dan dipertanggung jawabkan, namun demikian keduanya sama-sama memiliki

\footnotetext{
${ }^{20}$ Ahmad bin Hanbal, Musnad Ahmad III (Cet. I; Bairut: Alimun Kutub, 1419), h.

${ }^{21}$ A. Ghozali Masroeri, "Rukyatul Hilal, Pengertian dan Aplikasinya", disampaikan dalam Musyawarah Kerja dan Evaluasi Hisab Rukyat Tahun 2008 yang diselenggarakan oleh Badan Hisab Rukyat Departemen Agama RI di Ciawi Bogor tanggal 27-29 Februari 2008 h. 7 .

${ }^{22}$ Encup Supriatna, Hisab Rukyat dan Aplikasinya, (Bandung : PT Rafika Aditama, 2007),
} 
kelebihan dan kekurangan. Sebagaimana ungkapan H.A Mukti Ali dalam Musyawarah hisab dan Rukyat tahun 1977 bahwa hisab yang benar akan bisa dibuktikan dengan rukyat yang benar karena keduanya mempunyai objek yang sama yaitu hilal. $^{23}$ Dalam perkembangannya persoalan penetapan awal bulan kamariyah secara garis besar terdapat dua pemikiran atau sistem yang berbeda. Hal tersebut disebabkan adanya perbedaan dasar dan interpretasi serta pemahaman teks yang heterogen. Oleh karena itu, penulis mencoba menguraikan pemikiran tersebut.

\section{a. Metode Hisab}

Kata hisab berasal dari bahasa arab yaitu حسب- يحسب- حساب yang artinya menghitung, ${ }^{24}$ mengira dan membilang. ${ }^{25}$ Dalam bahasa inggris kata ini disebut Arithmatik yaitu ilmu hitung. ${ }^{26}$ Ilmu pengetahuan yang membahas tentang seluk beluk perhitungan. "hisab" itu sendiri berarti hitung, jadi ilmu hisab ${ }^{27}$ adalah ilmu hitung. Ilmu hisab sering digunakan dalam ilmu falak untuk memperkirakan posisi matahari dan bulan terhadap bumi. ${ }^{28}$

Al-Qur'an menyebutkan pengertian hisab atau aritmatic ternyata tidak semata-mata berarti perhitungan namun memiliki makna lain seperti batas, hari kiamat dan tanggung jawab. Dari akar kata hasaba, sebagai kata benda, kata ini disebut sebanyak 25 kali dalam al-Qur'an. Namun, hisab yang dimaksud dalam studi ini adalah metode untuk mengetahui hilal. Dalam literature klasik ilmu hisab

${ }^{23}$ A. Wasit Aulawi, Laporan Musyawarah Nasional Hisab dan Rukyat Tahun 1977 (Jakarta: Ditbinbapera, 1977), h. 1-5.

${ }^{24}$ Ahmad Warson Munawwir, Al-Munawir: Kamus Arab Indonesia, h. 261-261.

${ }^{25}$ Loius Maeluf, al-Munjid fi al-Lughah Dar al-Masyruq (Beirut : Maktabah Al-Tajriyah Al-Kubro, 1986), h.132.

${ }^{26}$ John M, Echols, Kamus Inggris Indonesia (Jakarta: PT Gramedia, 2005), h. 37.

${ }^{27}$ Ilmu hisab yang dimaksud disini adalah ilmu hisab sebagai ilmu falak yang biasa digunakan umat islam dalam proses penentuan berbagai hal dalam praktik ibadah. Ia hanya memberikan hasil perhitungan terkait persoalan waktu dan posisi saja. Lihat Encup Supriatna, Hisab Rukyat dan Aplikasinya, h. 2.

${ }^{28}$ Encup Supriatna, Hisab Rukyat dan Aplikasinya, h.2 
sering disebut sebagai ilmu falak, miqat, rasd dan haiah. Bahkan sering pula disamakan dengan astronomi. ${ }^{29}$

Sehingga dalam kitab suci al-Qur'an ada beberapa ayat yang menjelaskan kata hisab yang berkaitan dengan penentuan awal bulan qamariyah antara lain dalam surat al-Isra/17: 12, Yunus/10: 5 dan ar-Rahman/55:5.

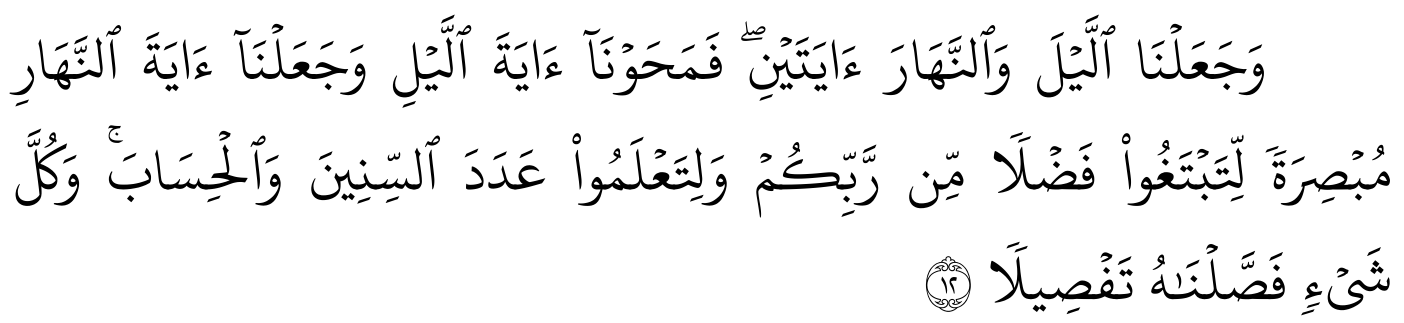

Terjemahnya:

Dan Kami jadikan malam dan siang sebagai dua tanda, lalu Kami hapuskan tanda malam dan Kami jadikan tanda siang itu terang, agar kamu mencari kurnia dari Tuhanmu, dan supaya kamu mengetahui bilangan tahun-tahun dan perhitungan. Dan segala sesuatu telah Kami terangkan dengan jelas. ${ }^{30}$
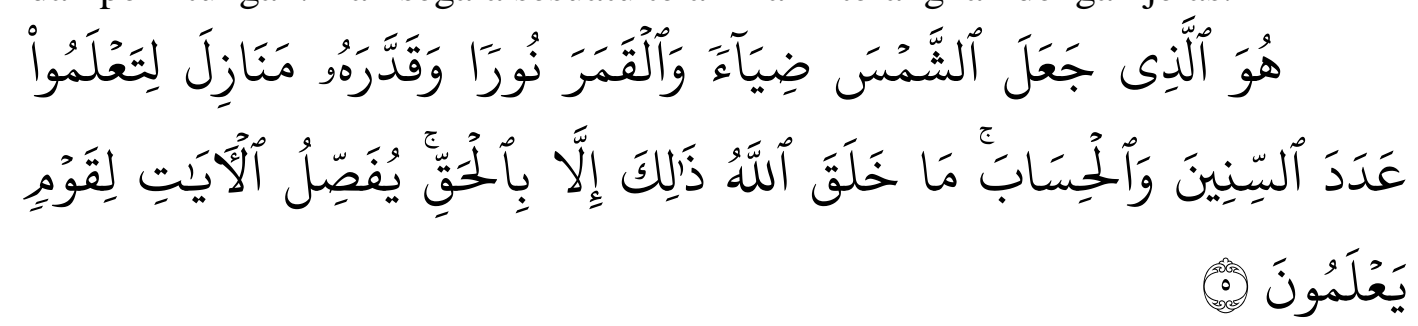

Terjemahnya:

Dialah yang menjadikan matahari bersinar dan bulan bercahaya dan ditetapkan-Nya manzilah-manzilah (tempat-tempat) bagi perjalanan bulan itu, supaya kamu mengetahui bilangan tahun dan perhitungan (waktu). Allah tidak menciptakan yang demikian itu melainkan dengan hak. Dia menjelaskan tandatanda (kebesaran-Nya) kepada orang-orang yang mengetahui. ${ }^{31}$

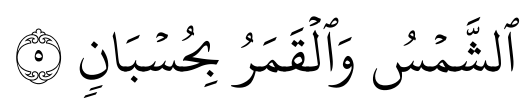

Terjemahnya:

Matahari dan bulan (beredar) menurut perhitungan. ${ }^{32}$

${ }^{29}$ Susiknan Azhari, ${ }^{29}$ Susiknan Azhari, Ilmu Falak Perjumpaan Khazanah Islam dan Sains Modern, h. 98.

${ }^{30}$ Kementerian Agama RI, al-Qur`an dan Terjemahnya, h. 283.

${ }^{31}$ Kementerian Agama RI, al-Qur`an dan Terjemahnya, h. 208.

${ }^{32}$ Kementerian Agama RI, al-Qur`an dan Terjemahnya, h. 531. 
Pada surat al-Isra':12 terdapat kalimat عَدَدَ ألسِّنِينَ وَأْلَحِنَابَّ Ibnu Abbas dalamkitab Tafsirnya Tanwir al-Miqbas menjelaskan bahwa yang dimaksud bilangan tahun dan perhitungan adalah perhitungan hari, waktu dan bulan. ${ }^{33}$ Dalam kitab Tafsir al-Qur'an karim wa bi Ilhamisy Zubdah al-Tafsir min Fath al-

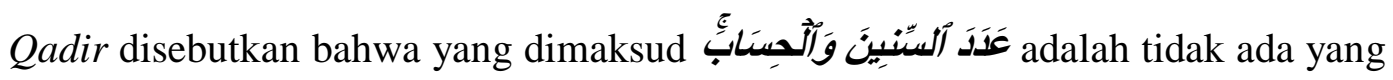
mengetahui bilangan tahun dan perhitungan bulan dan hari-hari, kecuali pergantian malam dan siang. ${ }^{34}$

Adapun hisab dalam konteks penentuan awal bulan kamariyah kegiatannya tidak lain untuk menentukan kedudukan hilal pada saat terbenam matahari yang diukur dengan derajat. Kegiatan ini dilakukan orang pada saat-saat terjadi ijtima (conjuntion) pada bulan-bulan kamariyah. Sehingga ilmu hisab Ilmu hisab juga diartikan sebagai ilmu untuk menentukan awal bulan kamariyah yang didasarkan kepada perdaran bulan mengelilingi bumi. ${ }^{35}$ Dengan metode ini dapat menetapkan awal bulan jauh-jauh hari sebelumnya, sehingga secara tidak langsung ilmu hisab sangat dibutuhkan dalam pembuatan kalender dan pedoman dalam pelaksanaan rukyatul hilal (melihat bulan). ${ }^{36}$

Dalam perkembangan selanjutnya "melihat hilal" tersebut tidak hanya dilakukan pada akhir Syakban dan Ramadhan saja, namun juga pada bulan-bulan lainnya terutama menjelang awal-awal bulan yang ada kaitannya dengan waktu pelaksanaan ibadah atau hari-hari besar Islam. Bahkan untuk kepentingan pengecekan hasil hisab. ${ }^{37}$

Secara histori, penentuan awal bulan untuk keperluan waktu ibadah ditentukan secara sederhana dengan pengamatan hilal sehingga sarana peralatan

${ }^{33}$ Abi Tahir Ya`kub Fayr al-Zabadi, Tanwir al-Miaqbas min Tafsir Ibnu Abbas, 234.

${ }^{34}$ Muhammad Sulayman Abdullah al-Asykar, Tafsir al-Qur`an karim wa bi Ilhamisy Zubdah al-Tafsir min Fath al-Qadir (Kairo: Maktabah ibn Taymiyah, 1410H/1990 M), h. 366.

${ }^{35}$ Bulan beredar mengelilingi bumi dalam waktu 27,32166 hari atau 27 hari 7 jam 43 menit 11,42 detik. Waktu edar ini dikenal dengan periode sideris. Lihat Susiknan Azhari, Ilmu Falak ( Perjumpaan Khazanah Islam dan Sains Modern), h.18

${ }^{36}$ Rukyatul Hilal adalah usaha melihat atau mengamati hilal di tempat terbuka dengan mata telanjang atau peralatan pada saat matahari terbenam menjelang bulan baru kamariah. Muhyiddin Khazin, Ilmu Falak Dalam Teori dan Praktik (Yogyakarta : Buana Pustaka, 2004), h. 69.

\footnotetext{
${ }^{37}$ Kementerian Agama RI, Pedoman Teknik Rukyat, h. 2.
} 
yang digunakan untuk pelaksanaan rukyat hanya dilakukan dengan mata telanjang, tanpa alat. Hanya melihat kearah ufuk bagian barat, tidak tertuju pada posisi tertentu. Dari keadaan seperti ini timbul istilah rukyat bi al'ain dan rukyat bi al'fi'li. ${ }^{38}$ Namun setelah kebudayaan manusia semakin maju, maka pelaksanaan rukyat pun secara berangsur dilengkapi dengan sarana serta berkembang terus menuju kesempurnaan sesuai dengan perkembangan teknologi.

Hanya saja, ketika melakukan rukyat matahari pada saat itu terbenam atau sesaat setelah itu langit sebelah barat berwarna kuning kemerah-merahan. Sehingga, antara cahaya hilal yang putih kekuning-kuningan dengan warna langit yang melatar belakanginya tidak begitu kontras. Oleh sebab itu, bagi mata yang kurang terlatih melakukan rukyat tentunya akan menemukan kesulitan menentukan hilal yang dimaksudkan. Apalagi apabila di ufuk barat terdapat awan tipis atau awan tebal tidak merata atau bahkan orang yang melakukan rukyat tidak mengetahui pada posisi mana dimungkinkan hilal akan tampak, tentunya akan mengalami kesulitan.

Begitu juga cara pelaksanaan rukyat pun tidak hanya sekedar melihat keatas ufuk bagian barat. Hal ini sebagai akibat ketidak tahuan ilmu astronomi dan ilmu hisab . Namun setelah kedua ilmu ini dapat dikuasai, pelaksanaan rukyat pun dapat dilakukan dengan lebih baik. Pelaksana dapat mengarahkan alatnya pada posisi dimana diperkirakan hilal berada. ${ }^{39}$ Untuk mengetahui penampakan hilal ini tentunya perlu dilakukan pengawasan dengan mata pada akhir bulan kamariyah guna menentukan apakah hilal sudah Nampak atau belum. ${ }^{40}$

Di dalam al-Qur`an Surat al-Baqarah/2: 189 yang dijadikan pijakan metode rukyat ini digunakan, yakni:

\footnotetext{
${ }^{38}$ Pedoman Rukyat dan Hisab Nahdatul Ulama, (Jakarta: Lajnah Falakiyah PBNU, 2006), h. 24 .

${ }^{39}$ Muhyiddin Khazin, Ilmu Falak Dalam Teori dan Praktik, h. 174.

${ }^{40}$ Ali Sayuthi, Ilmu Falak (Jakarta:PT. Raja Grafindo Persada, 1997),h. 105.
} 


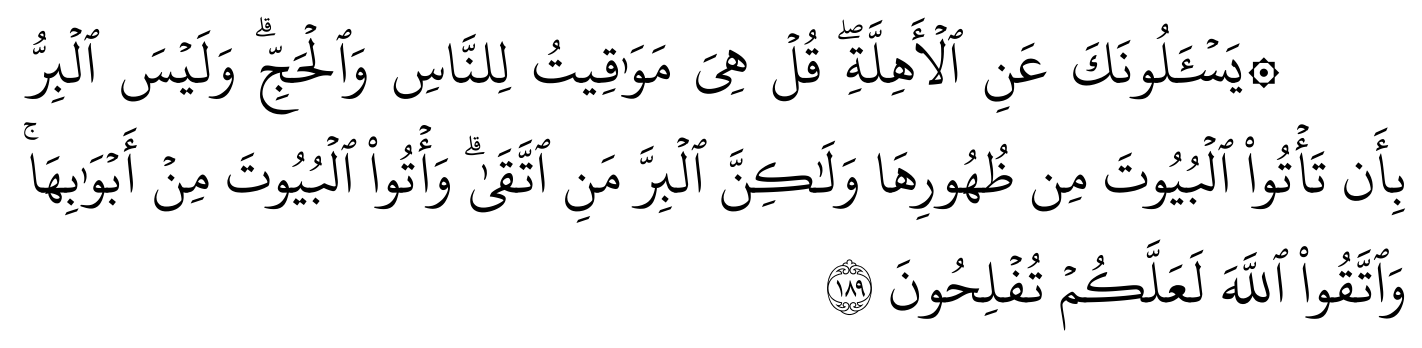

Terjemahnya:

Mereka bertanya kepadamu tentang bulan sabit. Katakanlah: "Bulan sabit itu adalah tanda-tanda waktu bagi manusia dan (bagi ibadat) haji; Dan bukanlah kebajikan memasuki rumah-rumah dari belakangnya, akan tetapi kebajikan itu ialah kebajikan orang yang bertakwa. Dan masuklah ke rumah-rumah itu dari pintu-pintunya; dan bertakwalah kepada Allah agar kamu beruntung. ${ }^{41}$

Kemudian dalam hadits yang popular dikalangan mazhab ru'yah yang diriwayatkan oleh Imam Bukhari:

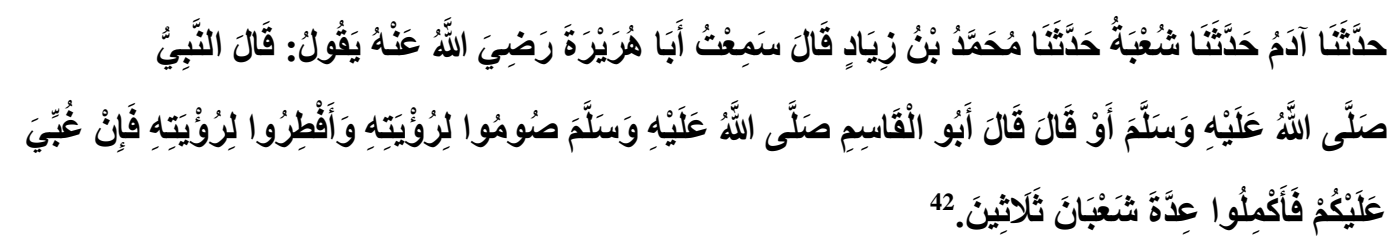

Artinya:

Berpuasalah karena kamu melihat hilal dan berbukalah karena kamu melihat hilal, apabila hilal itu tertutup kabut olehmu maka sempurnakanlah bilangan sya`ban 30 hari. $^{43}$

Dalil tersebut menunjukkan bahwa pengunaan metode rukyat al-hilal ini telah dilakukan sejak Nabi Muhammad SAW, Perintah Nabi di atas meka jelas bahwa pergantian bulan kamariyah ini di tandai dengan munculnya hilal, hal tersebut menjadi patokan utama dalam metode ini, akan tetapi di Indonesia metode ini sering sekali terkendala oleh cuaca sehingga pada saat matahari terbenam hilal yang seharusnya nampak akan tetapi menjadi tidan nampak karena tertutup oleh awan. Kemudian apabila hilal memang tidak dapat dilihat, merujuk dari hadits di atas maka bulan yang sedang berjalan digenapkan menjadi 30 hari.

\footnotetext{
${ }^{41}$ Kementerian Agama RI, al-Qur`an dan Terjemahnya, h. 29.

${ }^{42}$ Imām Abī 'Abdillāh Muhammad bin Ismā’̄il al-Bukhārī, Șaḥ̄ḥ Bukhārī, (Lebanon:
} Dār Kutub al-'Ilmiyyah, 2009), h. 470.

\footnotetext{
${ }^{43}$ Rahmatiah, Analisis Perbedaan Persepsi Ahli Hisab dan Ahli Rukyat dalam Penentuan Awal Bulan Qamariyah (Cet. I;Makassar: Alauddin Press, 2014), 40-41.
} 
Dari hadis tersebut jelas bahwa hilal adalah patokan utama yang dijadikan sebagai permualan awal bulan kamariyah, sehingga metode rukyat al-hilal digunakan untuk menentukan awal bulan dengan cara melihat hilal secara langsung atau dengan bantuan alat yang menunjang untuk dapat melihat hilal tersebut.

Menurut Imam Hanafi dan Maliki penanggalan kamariyah harus sama di dalam satu wilayah hukum suatu negara. Menurut Imam Hambali, kesamaan tanggal kamariyah ini harus berlaku di seluruh dunia di bagian malam dan siang yang sama. Sedangkan menurut Imam Syafi'i, penanggalan kamariyah ini hanya berlaku di tempat-tempat yang berdekatan sejauh jarak yang dikatakan satu matla. ${ }^{44}$ Dalam prakteknya batas matla' ini tidak jelas, sehingga muncul wilayat al hukmi. ${ }^{45}$

Indonesia menganut prinsip wilayah al-hukmi yakni bahwa bila hilal terlihat di manapun dalam wilayah wawasan nusantara, maka dianggap berlaku di seluruh wilayah Indonesia. ${ }^{46}$ Meskipun wilayah Indonesia dilewati oleh garis penanggalan Islam Internasional yang secara teknis berarti bahwa wilayah Indonesia terbagi atas dua bagian yang mempunyai tanggal hijriah yang berbeda, maka seluruh umat Islam di Indonesia melaksanakan ibadah puasa dan berhari raya secara serentak.

Selain dua masalah di atas, yang termasuk problem teknis adalah masalah yang ditimbulkan oleh perbedaan garis tanggal. ${ }^{47}$ Akibatnya suatu berita rukyat akan diterima serentak di segala penjuru dunia pada 24 zona waktu yang berbeda. Sehingga bisa saja terjadi, suatu berita diterima disaat yang sama pada tempat lain yang masih atau sudah pagi/siang. Jika hal ini tidak diperhatikan, maka bisa

\footnotetext{
${ }^{44}$ http://paramujaddida.wordpress.com. Diakses pada 9 Desember 2016

${ }^{45}$ http://osolihin.files.wordpress.com. Diakses pada 9 Desember 2016

${ }^{46}$ Farid Ruskanda, 100 Masalah Hisab dan Rukyat Telaah Syariah, Sains dan Teknologi (Jakarta: Gema Insani Press, 1996), h. 19.

${ }^{47}$ Garis batas tanggal adalah garis hayal yang berposisi pada meridian 180 dari Greenwich, yaitu yang melintasi Samudera Pasifik disebut juga International Date Line. Dengan perjanjianInternasional bahwa semua orang yang melewati garis batas tanggal ini perlu mengubah tanggal (walau waktu lokal tetap sama). Sebelah barat garis batas, satu hari lebih maju daripada tempat yang berada di timurnya. Lihat Muhyiddin Khazin, Kamus Ilmu Falak, (Cet. I; Yogyakarta: BuanaPustaka, 2005), h. 25.
} 
terjadi, suatu daerah hanya berpuasa 28 hari, sebab harus serentak mengikuti rukyat daerah lain. ${ }^{48}$

Rukyat yang dapat dijadikan dasar penetapan awal bulan Ramadan, Syawal, dan Dzulhijjah adalah rukyat yang muktabar, yakni rukyat yang dapat dipertanggung jawabkan secara hukum dan ilmiah. Rukyat yang demikian harus memenuhi syarat sebagai berikut ${ }^{49}$ :

a. Rukyat dilaksanakan pada saat matahari terbenam pada malam tanggal 29 atau 30 akhir bulan;

b. Rukyat dilaksanakan dalam keadaan cuaca cerah tanpa penghalang antara perukyat dan hilal;

c. Rukyat dilaksanakan dalam keadaan hilal memungkinkan untuk dirukyat (Imkan ar-Rukyat);

d. Hilal yang dilihat harus berada di antara wilayah titik barat 30 derajat ke selatan dan 30 derajat ke utara.

Adapun mengenai syarat seorang perukyat ada beberapa persyaratan syahid (perukyatan hilal). Baik secara formil maupun materil, yaitu ${ }^{50}$ Syarat Formil meliputi Aqil Baligh atau sudah dewasa; Beragama islam,vLaki-laki atau perempuan; Sehat akalnya; Mampu melakukan rukyat; Jujur, adil dan dapat dipercaya; Jumlah perukyat lebih dari satu orang; Mengucapkan sumpah kesaksian rukyatul hilal. Sedangkan syarat Materil meliputi Perukyat menerangkan sendiri dan melihat sendiri dengan mata kepala maupun menggunakan alat, bahwa ia melihat hilal;Perukyat mengetahui benar-benar bagaimana proses melihat hilal, yakni kapan waktunya, di mana tempatnya, berapa lama melihat, di mana letak, arah posisi dan keadaan hilal yang dilihat, serta bagaimana kecerahan cuaca langit/horizon saat hilal dapat dilihat; Keterangan hasil rukyat yang dilaporkan oleh perukyat tidak bertenyangan dengan

\footnotetext{
${ }^{48}$ http://osolihin.files.wordpress.com. Diakses pada 9 Desember 2016.

${ }^{49}$ Noor Ahmad SS, Menuju Cara Rukyat yang Akurat, Makalah pada Lokakarya Imsakiyah Ramadan 1427H/2006M se Jawa Tengah dan Daerah Istimewa Yogyakarta yang diselenggarakan oleh PPM IAIN Walisongo Semarang, 2006. h, 5.

${ }^{50}$ PWNU Jawa Timur, Penolakan Pemerintah terhadap Hasil Rukyatul Hila>l, http://www.pesantrenvirtual.com. Diakses tanggal 14 Juni 2017.
} 
akal sehat perhitungan ilmu hisab, kaidah ilmu pengetahuan dan kaidah-kaidah hukum Islam. ${ }^{51}$

\section{B. Profile Singkat tentang Jamaah An-Nadzir Jamaah Naksabandiyah di Kabupaten Gowa}

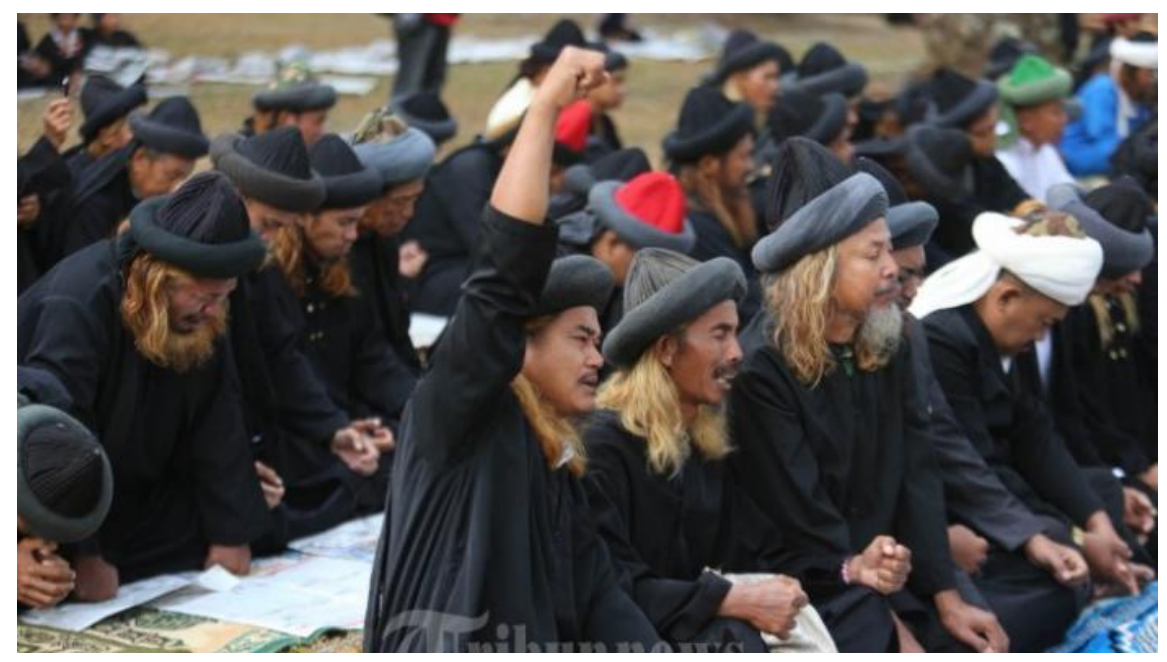

Jemaah An-Nadzir mempunyai ciri-ciri menggunakan sorban dan jubah, berambut pirang dan berbaju warna hitam-hitam, memakai celak bagi laki-laki. Sedangkan perempuan menggunakan cadar penutup muka dan jilbab besar.

Menurut Lukman ${ }^{52}$, kata An-Nadzir tersebut dari bahasa Arab yang artinya pemberi peringatan, bukan hanya pengikutnya melainkan juga masyarakat umum. Saat ini jumlah jamaah An-Nadzir sekitar 1.000 orang. Sedangkan tarekat Naqshbandiyah atau Naqsyabandiyah merupakan salah satu tarekat yang luas penyebarannya, umumnya di wilayah Asia, Bosnia-Herzegovina, dan wilayah Dagestan, Russia.

Tarekat ini mengutamakan pada pemahaman hakikat dan tasauf yang mengandung unsur-unsur pemahaman rohani yang spesifik, seperti tentang rasa atau "zok". Di dalam pemahaman yang meng"isbat"kan zat ketuhanan dan "isbat" akan sifat "maanawiyah" yang maktub di dalam "roh" anak-anak adam maupun

51 PWNU Jawa Timur, Penolakan Pemerintah terhadap Hasil Rukyatul Hila>l, http://www.pesantrenvirtual.com. Diakses tanggal 14 Juni 2017.

${ }^{52}$ Salah seorang amir dari Jemaah an nadzir yang disepakati menggantikan dg. Rangka. 
pengakuan di dalam "fanabillah" mahupun berkekalan dlam "bakabillah" yang melibatkan zikir-zikir hati (hudurun kalbu)

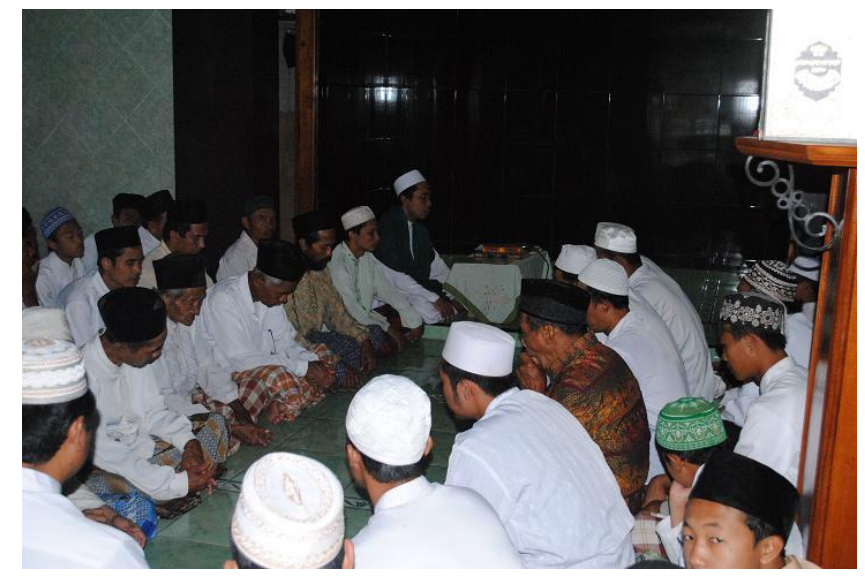

Tarekat merupakan sebuah organisasi tasawuf dibawah pimpinan seorang Syeikh yang menerapkan ajarannya kepada para murid-muridnya. Tareqat juga dimaksudkan sebagai suatu jalan yang dilalui oleh calon sufi dalam mencapai ma'rifat. Tidak mudah bagi seorang sufi untuk mencapai titik puncak yang harus dicapai olehnya dalam menjalani kehidupan bertasawuf. Sehingga pilihan lain dari hal ini adalah menjalaninya dengan kehidupan bertareqat.

Dalam perkembangannya, Tareqat sebagai suatu organisasi keagamaan kaum sufi sudah banyak lahir dengan corak yang berbeda. Ini sudah berkembang pesat dan tersebar ke Asia Tenggara, Asia Tengah, Afrika Timur, Afrika Utara, India, Iran dan Turki. Perbedaan-perbedaan tersebut dalam realitasnya mengarah kepada tujuan yang sama, yaitu berada sedekat mungkin dengan Tuhan. Karena Tareqat merupakan sebuah Organisasi yang lahir dari seorang Syeikh yang berniat ingin melestarikan ajaran-ajaran kaum sufi maka masing-masing dari syikeh tersebut tentu punya cara tersendiri dalam pengembangannya tersebut. Terbukti dengan lahirnya tarekat tersebut semakin berbeda pulalah metode-metode yang digunakan.

Demikian halnya tarekat naksyabandiyah yang berada di lokasi kecamatan Pattallasang, kabupaten Gowa. Keberadaannya mengalami kebaharuan, dari sisi pemimpin dan jamaah. Pemilihan imam sebagai pengganti pemimpin yang telah 
mangkat, langsung diganti oleh keturunan langsungnya, dengan tanpa melihat latar belakang kematangan umur dan pengalaman spritualnya. Kejadian ini berakibat munculnya perbedaan dan penyelewengan dari ajaran semula, sebab dikembangkan langsung oleh pemimpin yang ditunjuk.

Kesiapan mental dan kedewasaan spiritual sangat dibutuhkan dalam rangka membawa jamaah kepada kemurnian tarekat, namun kenyataannya seiring dengan perkembangan zaman yang mengglobal. Tarekat naqsabandiyah pun mengalami perbedaan satu sama lain, dsatu sisi tarekat naksabandiyah mereka menamakan diri dan jamaahnya sebagai jamaah kasabandiyah, namun sebenarnya adalah khalwatiyah yang menggolongkan diri dan jamaahnya sebagai kasabandiyah.

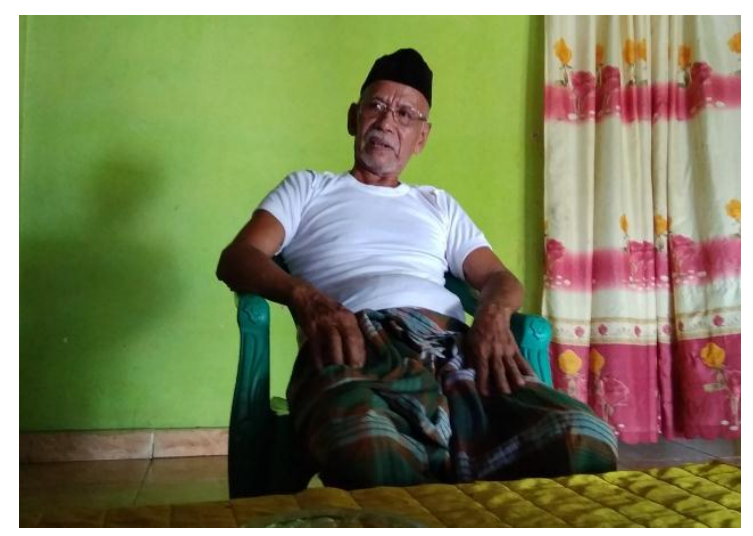

Warga memanggilnya Daeng Rala, beliau ditunjuk sebagai tetua atau Anro Gurunna jamaah kasabandiyah setelah tetua sebelumnya wafat. Daeng Rala merupakan seorang pegawai ketika ditunjuk oleh para pengikutnya dan bertugas menuntun jamaahnya yang ingin belajar agama. Ajaran yang mereka pegang hampir sama dengan ajaran umat Islam pada umumnya, dan merekapun mengikuti pemerintah dalam penentuan hari raya ataupun hari besar Islam lainnya.

Golongan berikutnya adalah pengikut tarekat khalwatiyah syekh Yusuf Gowa, yang dibawa kepemimpinan Puang La'lang. 


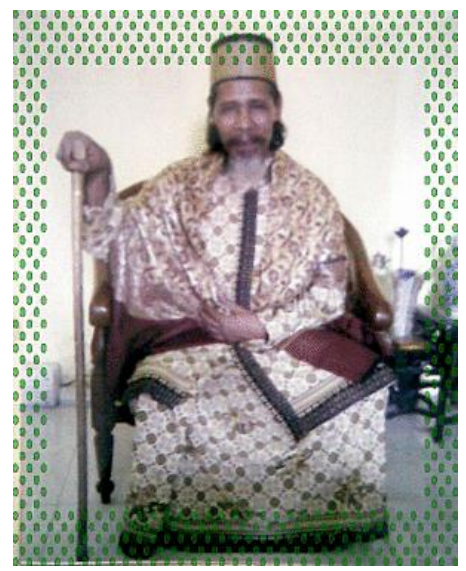

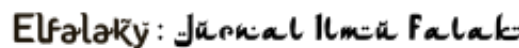

Vol 3, No. 1 Tahun 2019 M/1440 H

Profile jamaah Tahjul Khalwatiyah Syekh Yusuf

Al-Habib Syeikh Sayyid Sulthan Ahmad Ali Muhammad Myrami AlKhalwaty Qaddasallahu Sirrahu Al-Makassary Al-Bugisy Al-Buthuny (Syeikh Andi Malakuti Petta Karaeng La'lang).

\section{Metode Hisab dan rukyat jamaah an-Nadzir dan Naksabandiyah di kabupaten Gowa}

\section{Metode Hisab dan rukyat jamaah an-Nadzir kabupaten Gowa}

Penentuan awal bulan kamariyah pada jamaah an-nadzir didukung oleh keyakinan terhadap penerapan dalam penentuan yang dilakukan oleh Rasulullah saw. Menurutnya, penentuan awal bulan kamariyah merupakan ilmu yang diturunkan dan sampai kepada mereka dan diyakini secara turun temurun dari guru-gurunya. Ada dua indikator yang dijadikan sebagai metode dalam penentuan awal Bulan Kamariyah, yakni:

Dalam penentuan awal dan akhir bulan kamariyah ditentukan dengan mengambil sumber dalil yang sama yakni hadis Rasulullah saw tentang "Berpuasalah kalian karena melihat bulan, dan berbukalah kalian karena melihat bulan". Namun, dalam konteks (persfektif) bulan yang berbeda. Hal ini disebabkan:

Pertama, guru kami menyampaikan bahwa bulan yang menjadi pengamatan awal kami adalah bulan akhir yang terbit di sebelah Timur bukan bulan yang baru terbit di Barat. Hal ini agar memudahkan kita dalam memahami konteks bulan (hilal) dalam melihat bulan, jelas, nyata, bisa diukur. Beliau 
mengatakan dalam menafsirkan hadis tersebut bahwa intailah/amatilah bulan ramadan pada bulan syakban. Mengintai disini adalah sesuatu yang belum terjadi namun bisa diprediksi dan bisa disimpulkan sebagai bentuk keyakinan. Maka mengintai bulan ramadan yang dimaksud adalah mengintai akhir bulan syakban. Sebab jika kita menjumpai akhir syakban yang benar pasti kita menemukan awal ramadan yang benar. Sebaliknya, jika salah menentukan akhir syakban pasti salah juga menentukan awal bulan ramadan dan pasti salah rangkaian setelahnya.

Kedua, dalil aqlinya adalah sangat mustahil kita jadikan barometer bahwa bulan yang terbit di Barat sebagai bulan baru ketika kita memberikan patokan berdasarkan derajat (2 derajat, 3 derajat dan seterusnya). Sebab, bulan demikian berpotensi muncul 10 derajat di Bawah Nol atau 6 derajat di Bawah Nol. Hal ini berdasarkan dalil bahwa lingkaran bulan penuh sebesar 360 derajat dibagi 30 malam sebagai estimasinya maka setiap malam bulan terbit 12 derajat di Barat sampai mencapai 180 derajat. Oleh sebab itu, barometernya adalah bulan purnamanya. Rata-rata bulan purnama terbit pada posisi 6 atau 10 derajat disebelah timur di Sore hari, karena sebelumnya bulan terbit disebelah bulan pertamanya pada 6 atau 10 derajat, maka posisi purnamanya terbit pada posisi 180 derajat dikurang 10 derajat adalah 170 derajat $(180-10=170)$. Sebab perjalanan bulan itu konstan, 360 derajat dibagi dua maka 180 derajat perjalan bulan dari timur ke barat. Pastinya bahwa, ketika kita mengacu ketinggian bulan setiap malamnya pada konteks derajat maka bulan yang selalu diamati menggunakan teropong pada tim rukyat pemerintah di sebelah Barat dengan menemukan indikasi 2 derajat lebih itu bukan awal bulan (hari pertama bulan tersebut) namun hari kedua. Sebab bulan akan menempuh perjalanan 24 jam menuju ke Barat kembali terbit di Malam kedua, bulan harus menyisihkan jumlah 12 derajat naik, namun karena bulan terbit 10 derajat di Bawah Nol, maka dia menyisihkan 10 derajat sehingga bulan terbit di Barat kembali pada posisi 2 derajat sehingga cukuplah bulan 12 derajat akan naik dan seterusnya konstan seperti itu sampai mencapai 180 derajat pada bulan Purnama. Dalam pengamatan kami secara menyeluruh disesuaikan dengan waktu. Maka kami menemukan bahwa disetiap 
malam bulan terbit tepat 54 menit terutama 3 malam terakhir kita akan menemukan bulan terbit selama 54 menit dimana bulan terbit dalam bentuk yang serupa dengan hilal namun dinamakan bulan sabit. Selanjutnya akan diamati untuk menentukan awal bulan kamariyah.

Selanjutnya indikator kedua terjadi Bulan baru adalah fenomena Alam, yakni akan terjadi pasang tertinggi di Laut. Pasang puncak merupakan fenomena alam yang dipengaruh oleh garis astronomi (garis lurus) antara matahari dan Bulan serta Bumi. Hal ini disebabkan karena pada posisi ini gaya tarik/magnet sangat tinggi antara ketiga yang terjadi pada akhir Bulan. Ada dua kemungkinan peristiwa gravitasi yang akan terjadi yang mempengerahu terjadi air pasang yakni pada saat bulan purnama dan Bulan akhir. Pada bulan purnama terjadi pasang namun tidak terlalu tinggi. Sedangkan pada akhir Bulan air pasang lebih tinggi dari pada bulan purnama. Terdapat posko di Kolaka untuk mengamati air pasang tertinggi. Air pasang akan terjadi selama tujuh hari, misalnya pasang pada hari pertama memiliki ketinggian, hari kedua naik lebih tinggi pada hari pertama, sampai pada hari kelima pasang yang lebih tinggi dari sebelumnya dan ternyata pasang lebih rendah pada hari keenam dibanding hari kelima. Maka pasang pada hari kelima yang dicatat sebagai hari dimana terjadi pergantian bulan.

Metode penentuan awal bulan kamariyah yang digunakan oleh an-Nadzir ini pada dasarnya menggunakan metode hisab dan rukyat dan ditambah dengan fenomena alam yang disebut dengan air pasang tertinggi. Hisab dengan menghitung bulan yang terbit di akhir bulan syakban untuk menentukan awal ramadan, akhir ramadan untuk bulan syawal dan akhir bulan dzulqa'dah untuk awal bulan zulhijjah. Sedangkan acuan utama dalam rukyat sekaligus hisab kami adalah bulan purnama. Ketika terjadi purnama maka bulan sudah sampai pada malam yang 15 dimana indikasi bulan purnama adalah bulan yang terbit di Timur bersamaan dengan terbenamnya matahari di Barat dan di subuh harinya Bulan terbenam di Barat bersamaan dengan terbitnya fajar siddiq di Timur. Jika race terbitnya bulan dari Nol sampai fajar siddiq terbit ketiga hanya mencapai 54 menit maka yakin malam itu sudah habis artinya tidak akan ada lagi bulan baru. Contoh 
pada beberapa pengamatan kami terutama awal bulan ramadan khususnya akhir bulan. Fajar sadiq masuk pada pukul 05:30, terkadang pada pukul 05:10 (tergantung relatifitas perjalanan matahari) dimana ketinggian bulan berada pada ketinggian 6-10 derajat. Perbedaan antara fajar kazib dan fajar sadiq bisa dilihat pada cahaya yang muncul pada saat itu, yakni cahaya putih yang nampak berspotspot maka itu adalah fajar kazib. Jika berubah warna dari kekuningan kemudian jingga sehingga membentuk cahaya garis maka itulah fajar sadiq. Inilah batasan bulan itu nampak, apabila estimasi waktu bulan itu nampak selama 54 menit menuju pada fajar sadiq maka yakinlah bahwa bulan itu telah habis, maka itulah akhir daripada bulan ramadan. Maka besoknya bulan berada di Barat meskipun tidak nampak (sebab penampakan hilal sangat tipis) dan malam kedua muncul pada ketinggian 2 derajat.

\section{Metode Hisab dan rukyat jamaah Naksabandiyah Kabupaten Gowa}

Dalam proses penerapannya kedua tarekat ini tidak menggunakan methode Hisab ataupun Rukyat untuk penentuan awal Ramadhan ataupun Syawal. Kasabandiyah mengikuti keputusan pemerintah dan mengikutinya tanpa ada pertentangan. Sedangkan Tahjul Khalwaty memiliki kitab yang dipercaya berasal dari Nabi Muhammad yang merangkum Almanak seumur hidup dan berisi penanggalan hingga akhir zaman. Penentuan Ramadhan dan Syawal langsung mereka lihat dalam kitab tersebut. 


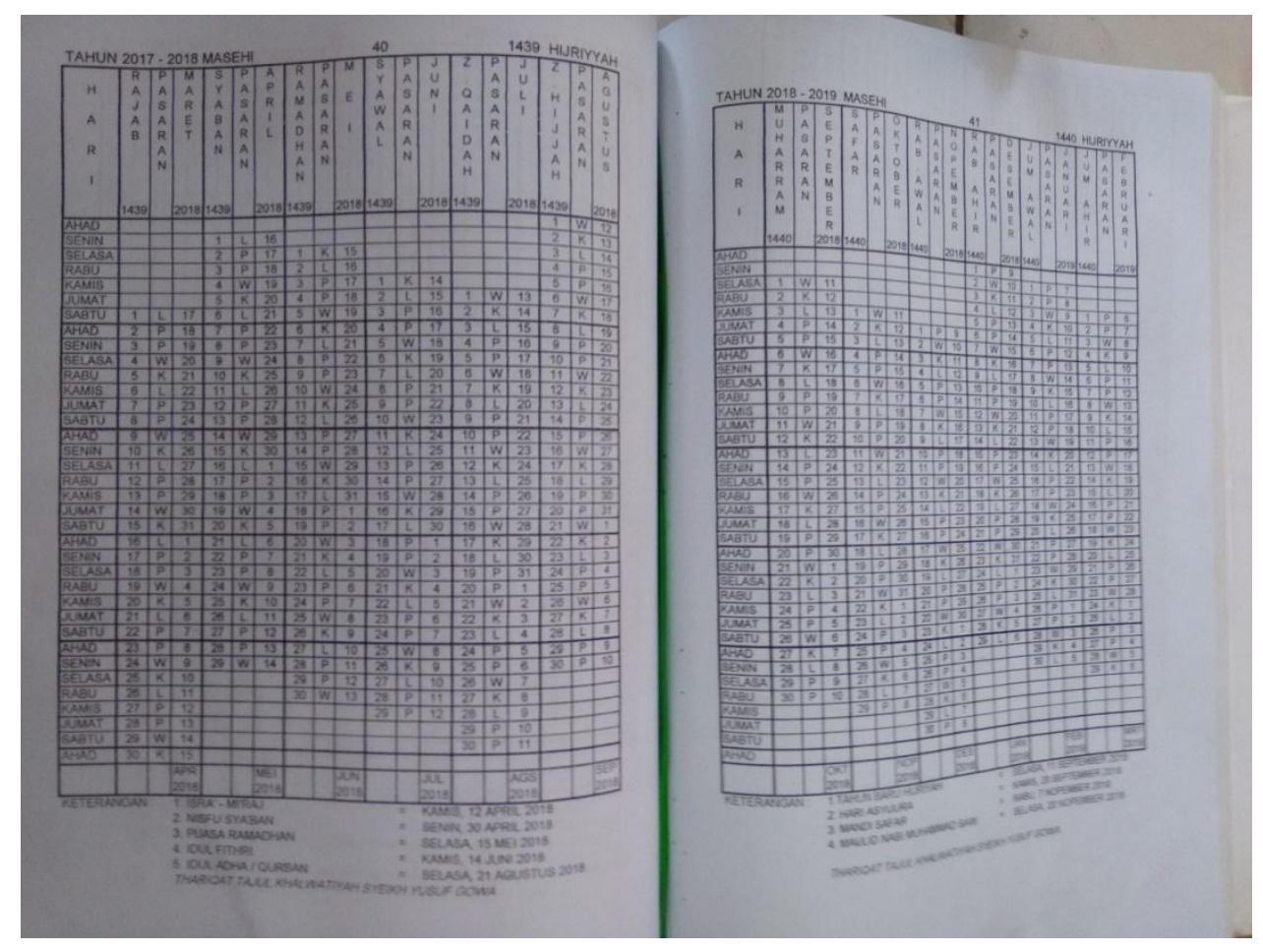

Seperti yang telah penulis utarakan sebelumnya, dalam pengambilan keputusan penetapan awal Ramadhan dan Syawal Kasabandiyah dan Tahjul Khalwaty memiliki cara yang berbeda. Kasabandiyah mengikuti ketetapan pemerintah tanpa ada pengaruh dari alam ataupun pengaruh lainnya sedangkan Tahjul Khalwaty langsung merujuk pada kitab mereka yang telah berisi penanggalan hingga akhir zaman di tahun 2090 tanpa harus memperhatikan fenomena alam. Mereka hanya tunduk kepada pemimpinnya untuk merujuk pada kitab sehingga mereka memiliki tepat 30 hari di bulan Ramadhan setiap tahunnya.

\section{Pengaruh imam pada pengambilan keputusan dalam menetapkan} awal Ramadhan dan Syawal pada jamaah an-Nadzir dan Naksabandiyah di kabupaten Gowa.

Imam ( إمام ) berarti pemimpin. Dalam arti biasa Imam adalah individu yang dilantik bagi memimpin golongan para jemaah ketika melakukan ibadah solat atau amal kebaikan. Erti lain ialah mereka yang diberi kepercayaan menjadi pemimpin bagi satu kumpulan untuk memimpin ke jalan yang benar (Khalifah). ${ }^{53}$

\footnotetext{
${ }^{53}$ https://ms.wikipedia.org/wiki/Imam
} 
Syekh abu Zahra dari kelompok sunni menyamakan arti khalifah dengan imamah, beliau berkata:

“ imamah itu juga sebagai khalifah, sebab orang yang menjadi khalifah adalah penguasa tertinggi bagi umat Islam yang menggantikan Rasulullahsaw. Khalifah juga disebut sebagai imam (pemimpin) yang wajib ditaati. Manusia berjalan di belakangnya, sebagaimana manusia shalat di belakang imam. ,54

Istilah imam yang berkaitan dengan kepemimpinan umat pertama kali disandang oleh imam Ali putra Abu Thalib, yang kemudian imamah dipegang oleh para putra Ali, yang kemudian disebut syi'ah Rafidhah atau syi'ah itsna'Asyariah. ${ }^{55}$

Imam adalah seseorang yang dituakan, dianggap mampu menaungi ummat yang dipimpinnya, bahkan imam adalah sangat disakralkan, dan wajib ditaati.

Ketaatan pada seorang guru, sekaligus sebagai imam, dan keyakinan akan keselamatan. Keyakinan dipahami sebagai bentuk ketaatan pada seorang imam, dan apapun yang dilakukan adalah dalam rangka mengimplikasi konsep ketaatan dan konsekwensi dari sebuah keyakinan keselamatan. konsep guru dan sekaligus imam adalah pemimpin yang harus ditaati, karena gurunya sebagai imam sudah menjamin keselamatan jamaahnya, sehingga mereka hanya meyakini bahwa semua persoalan ibadah dan aktivitas lainnya sudah dilakoni dan dipertanggungjawabkan oleh gurunya, yang sebelumnya dia tidak mengetahui secara utuh, Sesuai kalimatnya:

“... apa yang kuajarkan kepada kamu adalah kebenaran dari Allah dan rasulNya, yang apabila ini salah karena kamu taat kepadaku, aku yang bertanggung jawab, aku bebaskan kjamu dari tuntutan Allah, biarkanlah aku yang memikul neraka jahannam beserta tujuh generasi cucu turunanmu akuklah yang pikul neraka jahannam. Garansi inilah yang kami lakukan yang jaminan garansi itu, sehingga kami menjalankan saja."

\footnotetext{
${ }^{54}$ Dr. Ali As-salus, Imam dan khilafah dalam Tinjauan Syar'l, (Gema Insani Press, Jakarta), h.16

${ }^{55}$ https://ms.wikipedia.org/wiki/Imam
} 
Begitu pula halnya dengan peran imam bagi jamaah naqsyabandiyah, mereka meyakini kegiatan iabadah yang dilakukan apabila mereka salah, maka guru atau imam merekalah yang memikul kesalahan itu. Berbeda dengan keyakinan umat muslim pada umumnya, yaitu

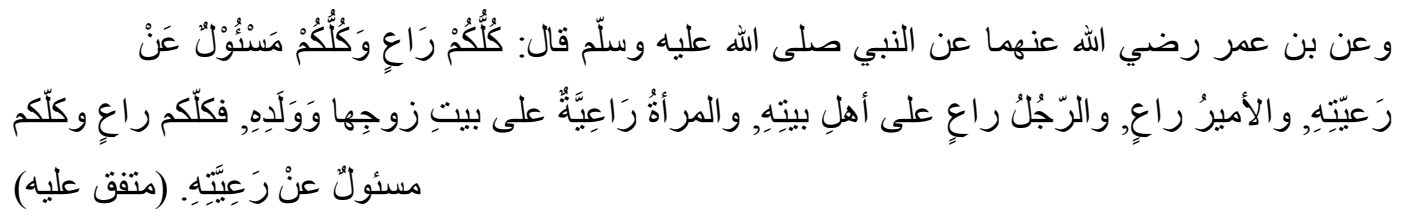

Artinya:

Dari Ibn Umar ra. Dari Nabi saw, beliau bersabda : “ Kalian adalah pemimpin dan kalian akan dimintai pertanggungjawaban atas kepemimpinan kalian. Seorang penguasa adalah pemimpin, seorang suami adalah seorang pemimpin seluruh keluarganya, demikian pula seorang isteri adalah pemimpin atas rumah suami dan anaknya.Kalian adalah pemimpin yang akan dimintai pertanggungtawaban atas kepemimpinan kalian". (HR. Bukhari dan Muslim) ${ }^{56}$

Hadist diatas telah menerangkan bahwa setiap manusia adalah seorang pemimpin dan setiap pemimpin akan diminta pertanggung jawaban kelak di akhirat oleh Allah SWT., dan tak seorangpun mampu melepaskan diri dari tanggungjawabnya.. Menurut Imam Nawawi dalam kitabnya, al-Minhâj Syarh Sahîh Muslim bin al-Hujjâj, bahwa pemimpin harus adil. Harus melaksanakan tugas untuk kebaikan yang dipimpinnya.

Baik yang berikaitan dengan dunia atau akhirat. Imam Ibnu Bathal juga mengatakan bahwa setiap orang yang mendapatkan amanah (menjadi pemimpin) harus mengerahkan kemampuan untuk menjaga amanah itu. Sebab, kelak akan dimintai pertanggung jawaban tentang apa yang ada dalam amanahnya. Dengan demikian, pemimpin yang tidak amanah adalah berdosa.

Pemimpin yang tidak bertanggung jawab juga berdosa. Jika ada satu orang saja tidak baik, maka pemimpin kelak yang akan ditanya. Jika ada satu orang saja terlantar, tidak mendapatkan apa yang harus dia dapatkan, maka pemimpin yang akan mempetanggung jawabkannya di hadapan Allah.

Karena itulah seorang pemimpin seharusnya mengerti tentang pengertian pemimpin itu sendiri, tujuan dan betapa pentingnya tugas pemimpin itu. Dia tak hanya membawa satu orang tapi seluruh warga di bawah kepemimpinannya. 
Jadilah seorang pemimpin yang baik dan bertanggung jawab, karena setiap orang merupakan pemimpin. Jika setiap orang mempunyai rasa kepemimpinan dalam dirinya maka kehidupan akan damai dan sejahtera.

\section{Pengaruh fenomena alam terhadap pengambilan keputusan penetapan awal Ramadhan dan Syawal pada Jamaah an-Nadzir di Kabupaten Gowa}

Indikator lain rukyat yang bisa diamati dari sisi manual ketika sudah melihat terbit bulan di Barat dalam bentuk sabit tua maka dilihat jam berapa bulan sabit tersebut terbit sehingga diestimasi sisa 3 malam. Ketika muncul bulan sabit di Timur maka lihat saja dengan kain tipis warna hitam maka pada malam itu kita akan mendapatkan bulan akan terlihat 4 susun di mana tiga diantaranya merupakan bayangan dan satunya merupakan bulan sabit yang asli artinya malam tersebut adalah malam ketiga dari bulan baru. Tiga bayangan tersebut menunjukkan sekian malam lagi akan terbit maka dari sisi ini sudah bisa kita estimasi atau hisab mengenai perjalanan bulan sampai pada akhir bulan syakban misalnya dan awal bulan ramadan. Tentunya hal ini didukung dengan beberapa indikator yang telah saya sebutkan sebelumnya termasuk mengenai saat terjadi fenomena alam dimana pasang air di Laut mencapai puncaknya, agar tidak terjadi pengamatan yang menghasilkan pengamatan yang keliru. Ketiga metode ini merupakan satu kesatuan yang terjadi untuk menentukan awal bulan kamariyah yang saling menyesuaikan.

Dalam pengambilan keputusan penetapan awal Ramadhan dan Syawal Kasabandiyah dan Tahjul Khalwaty memiliki cara yang berbeda. Kasabandiyah mengikuti ketetapan pemerintah tanpa ada pengaruh dari alam ataupun pengaruh lainnya sedangkan Tahjul Khalwaty langsung merujuk pada kitab mereka yang telah berisi penanggalan hingga akhir zaman di tahun 2090 tanpa harus memperhatikan fenomena alam. Mereka hanya tunduk kepada pemimpinnya untuk merujuk pada kitab sehingga mereka memiliki tepat 30 hari di bulan Ramadhan setiap tahunnya. 
Berbeda dengan apa yang terdapat pada jamaah an Nadzir, pada jamaah Naksabandiyah di Kabupaten Gowa, mereka sama sekali tidak berpedoman pada fenomena alam pada penetapan awal bulan kamariyah, mereka terbiasa melakukan ritual keagamaan melalui zikir, dan persoalan penentuan kapan dimulai berpuasa, dan kapan berlebaran, mereka mengembalikan pada konsep dan ketentuan pemerintah, dan kembali pada buku yang diyakini datangnya dari nabi Muhammad saw.,

\section{E. KESIMPULAN}

1. Metode Hisab dan rukyat yang digunakan jamaah an-Nadzir adalah berpedoman pada hisab akhir bulan sedang rukyatnya berpedoman pada fenomena alam yaitu pasang surutnya air laut, Adapun pada jamaah Naksabandiyah kabupaten Gowa terbagi dua, yaitu ada yang ikut pemerintah sebab mereka hanya focus pada zikr khalwatiyah, namun pada golongan yang lainnya berpatokan pada buku yang doyakini kebenarannya turun dari Nabi saw, sebagai tuntunan dalam menetapkan awal bulan yaitu kitab al manak syekh Yusuf Gowa.

2. Pengaruh imam pada pengambilan keputusan dalam menetapkan awal ramadhan dan Syawal pada jamaah an-Nadzir.dan Naksabandiyah di kabupaten Gowa sangat besar sebab pemimpin dianggap sebagai orang yang mampu memikul kesalahan jamaahnyayang telah mengikuti ajarannya, sehingga neraka jahannampun dipikulnya bila apa yang diajarkan itu salah.

3. Pengaruh fenomena alam terhadap pengambilan keputusan penetapan awal Ramadhan dan Syawal pada Jamaah an-Nadzir sangat signifikan pengaruhnya, sebab meski hisab tidak mendukung akan tetapi air telah pasang maka itulah pertanda masuknya bulan baru; berbeda dengan jamaah Naksabandiyah di Kabupaten Gowa mereka ada yang ikut pada pengumuman pemerintah karena focus hanya pada zikir kepada Allah swt., dan kelompok naqsabandiyah lainnya adalah berpedoman pada alamanak yang telah dibuat dari tahun 1994 hingga $2090 \mathrm{M}$. 


\section{DAFTAR PUSTAKA}

Al-Quran al-karim

Ahmadi, Thoha. Astronomi Dalam Islam, Surabaya: Bina Ilmu. 1993

Al-Asqalani, Ahmad bin Ali bin Hajar, fathul Bari, Dar al-Fikr wa maktabah as-Salafiyah.

Al-Bukhari, Abu Abd. Ali Muhammad bin ismail, Shahih al-Bukhari, Beirut: Dar al-Fikr.

Abdullah, Taufik dan M. Rusli, Metodologi Penelitian Agama Sebuah Pengantar, Yogyakarta: t.p, 1989.

Abdurrahman. Asjmuni. Penentuan Awal Bulan Ramadlan dan Satu Syawal, dimuat dalam majalah Suara Muhammadiyah, No. 17/Th. Ke-83 (1-15 September 1998.

al-Baghdādī, Abdurrahman. Umatku Saatnya Bersatu Kembali; Telaah Kritis Perbedaan Awal dan Akhir Ramadhan, Jakarta: Insan Citra Media Utama, 2007.

al-Bukhārī, Imām Abī 'Abdillāh Muḥammad bin Ismā’ōl. Ṣaḥịh Bukhārī, , Lebanon: Dār Kutub al-'Ilmiyyah, 2009.

al-Busta@ny, Karim.Al-MunjibFiLLughahwa al-`alam, Bairut: Dar alMasyrik, 1973.

Al-Fairuzzabadi, Qamus al-Muhit, Bairut: Dar al-Fikr, 1995.

Ali, A. . The Quran Text, Translation and Commentory, Riyad: Amana Corp, 1403.

Alimuddin, Ilmu Falak II, Makassar: Alauddin Press, 2014.

al-Jawi, M. Shiddiq. Penentuan Awal Bulan Qamariyah Perspektif Hizbut Tahir Indonesia", Makalah oleh MajelisTarjih dan Tajdid PP Muhammadiyah Yogyakarta 27-30 Nopember 2008.

Al-Maroghi, Syaikh Ahmad Musthofa. Tafsir al-Maraghi jilid I, Kairo: Musthofa Al-Babi Al-Halabi, 1946.

Al-Syaukani, Muhammad bin 'Ali bin. Fathul al-Qadir al-Jami' Baina Fanni al-Riawayah Wa al-Dirayah min Ilmi al-tafsir, Juz I,Mesir, Dar al-Qafa' Mansurah, 1997M/1418H.

al-Zabadi, Abi Tahir Ya`kub . Tanwir al-Miaqbas min Tafsir Ibnu Abbas, Bairut: Dar al-Fikr, t.th.

Al-Zuhayliy, Wahbah. al-Tafsir al-Manar Juz 2,Beirut: Dar al-Fikr alMua'asir, $1411 \mathrm{H} / 1991 \mathrm{M}$.

Ash-Shabuni, Muhammad Aly. Shafwatut Tafasirjuz I, Bairut: Dar alKutub al-Islamiyah, t.th. 
Ash-Shiddieqy, TM. Hasbi, Perbedaan Mațā', Tidak Mengharuskan Kita Berlainan Hari Pada Memulai Puasa, Yogyakarta: Ladjnah Ta'lif wa al-Nasyr, Fakultas Syari'ah IAIN Sunan Kalijaga, 1971.

Asse, Ambo. Metode Hisab Rukyat dalam Persfektif Hadits Nabi saw, Makassar: Alauddin Press, 2011.

Aulawi, A. Wasit. Laporan Musyawarah Nasional Hisab dan Rukyat Tahun 1977, Jakarta: Ditbinbapera, 1977.

Ali, suyuti, M. Ilmu Falak I, Jakarta : Grafindo Persada

Katsir,A. 1979, Matahari, Bulan, dengan Hisab, jakarta

Nasim Butt. 1996, Sains dan Masyarakat Islam, Bandung, Pustaka Hidayat.

Nsution, Harum 1996, Islam Rasional (Gagasan Pemikiran), Jakarta: Mizan

Oceanograf, Hidro, Bimas Almanak Nautika, Terbit setiap tahun

Saleh Rodhi, moh. 1972, Rukyatul Islam, Jakarta, an-Nazamiyah

- $\quad$ http://daerah.sindonews.com

- $\quad$ http://etd.repository.ugm.ac.id/index.php?act=view\&buku-

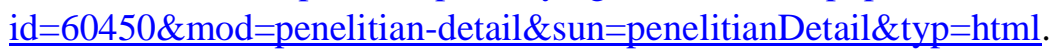

- $\quad$ Abdu Azis, varian-varian fundamentalisme Islam Indonesia, dalam Ahmad Syafi'i Mufid (Ed), Kasus-kasus Aliran/Paham keagamaan aktual di Indonesia, (Jakarta, CV.Prasasti, 2009).

- $\quad$ www.al-fikrah.com

- CL. Selltiz, at al., Research Methods in Social Relation, dalam M.

Burhan Bungim, Penelitian Kualitatif, (Jakarta, Kencana Prenada Media group, 2007). 